\title{
4. SITE 25
}

The Shipboard Scientific Party ${ }^{1}$

\section{SETTING AND PURPOSE}

The continental margin off the northeast coast of Brazil is depicted on hydrographic contour charts (Monaco, 1961; U. S. Naval Hydrographic Office, 1961, sheet 7) and physiographic diagrams (Heezen and Tharp, 1961 and 1968) as a region where numerous seamounts mark the base of the continental rise between Cape Calcanhar and the mouth of the Amazon. Recent surveys by ships of the Lamont-Doherty Geological Observatory have accumulated topographic and geophysical data which support the view that these features-interpreted in the published charts as isolated seamounts-are, in fact, the result of plotting numerous echo-sounder crossings of a narrow, nearly continuous, basement ridge, extending for a distance of 1300 kilometers parallel to the Brazil coast.

Hayes and Ewing (1968) have described the general features of this interesting structure lying about 150 kilometers seaward from the base of the continental slope, which they have termed the North Brazilian Ridge. Figure 1 shows the position of the Ridge axis, indicating a break of approximately 10 kilometers on the equator at $40^{\circ} \mathrm{W}$ longitude. The $R / V$ Vema Site Survey track for Site 25 is shown in this figure just southeast of the break; farther to the southeast the Ridge exhibits double parallel crests.

A detailed discussion of the North Brazilian Ridge is given in Hayes and Ewing (1970), and their findings may be summarized as follows:

1. The Ridge is located in deep water of approximately 3700 to 4000 meters near the base of a poorly developed continental rise. The crestal relief ranges from $\mathbf{3 0 0}$ meters to nearly $\mathbf{4 0 0 0}$ meters.

2. The Ridge is a narrow feature, only about 40 kilometers or less in width at its base, except in the

\footnotetext{
${ }^{1}$ Richard G. Bader, Institute of Marine and Atmospheric Sciences, University of Miami, Miami, Florida; Robert D. Gerard, Lamont-Doherty Geological Observatory of Columbia University, Palisades, New York; William E. Benson, National Science Foundation, Washington, D. C.; Hans M. Bolli, Swiss Federal Institute of Technology, Zurich, Switzerland; William W. Hay, Institute of Miami, Miami, Florida; W. Thomas Rothwell, Jr., Atlantic Richfield Company, Dallas, Texas; Michael H. Ruef, Woods Hole Oceanographic Institution, Woods Hole, Massachusetts; William R. Riedel, Scripps Institution of Oceanography, La Jolla, California; Fred L. Sayles, Woods Hole Oceanographic Institution, Woods Hole, Massachusetts.
}

double-crested portion, where the Ridge is about 75 kilometers wide. The cross-section of the Ridge is roughly symmetric.

3. Sediments are ponded on the continental side of the Ridge, with the differential depth due to the ponding ranging from about 250 meters to 750 meters.

4. There is no marked contrast in the sediments cored from the upper few meters on opposite sides of the Ridge.

5. There is no evidence in bottom photographs of strong bottom currents in the areas adjacent to the Ridge.

6. Bottom photographs taken on the steep flanks of the Ridge clearly show rock outcorps which are probably basalt.

7. The Ridge apparently aids in the isolation of the bottom water masses on its opposite sides.

8. Magnetic anomalies associated with the Ridge are characteristically less than 200 gammas peak to peak amplitude. Inferred values of effective magnetization of the Ridge are low, but do not rule out a possible basaltic composition.

9. The Ridge is gravimetrically compensated, and at least a portion of the compensation occurs at depths typical of the crust-mantle interface. The gravity data appear to rule out an origin due to downfaulting of a continental block.

10. Acoustic basement is observed at a depth below sea level of about 5 kilometers in the area of the Ceara Abyssal Plain, northeast of the Ridge. Acoustic basement is not observed landward of the Ridge.

11. A major portion of the topographic relief of the Ridge is associated with materials of compressional wave velocity $\mathrm{V}_{\mathrm{p}}<4 \mathrm{~km} / \mathrm{sec}$, considerably lower than velocities associated with layer $2\left(\mathrm{~V}_{\mathrm{p}} \approx 5 \mathrm{~km} / \mathrm{sec}\right)$ of the oceanic crust.

12. Two of the major fracture zones of the Equatorial Atlantic (Romanche, St. Pauls') have been traced westward into the proximity of the Ridge, but do not appear to be in any way structurally connected to it.

13. Heatflow values throughout the area are near to average oceanic basin values or slightly higher. The Ridge does not serve as a boundary in delineating different heatflow provinces. 


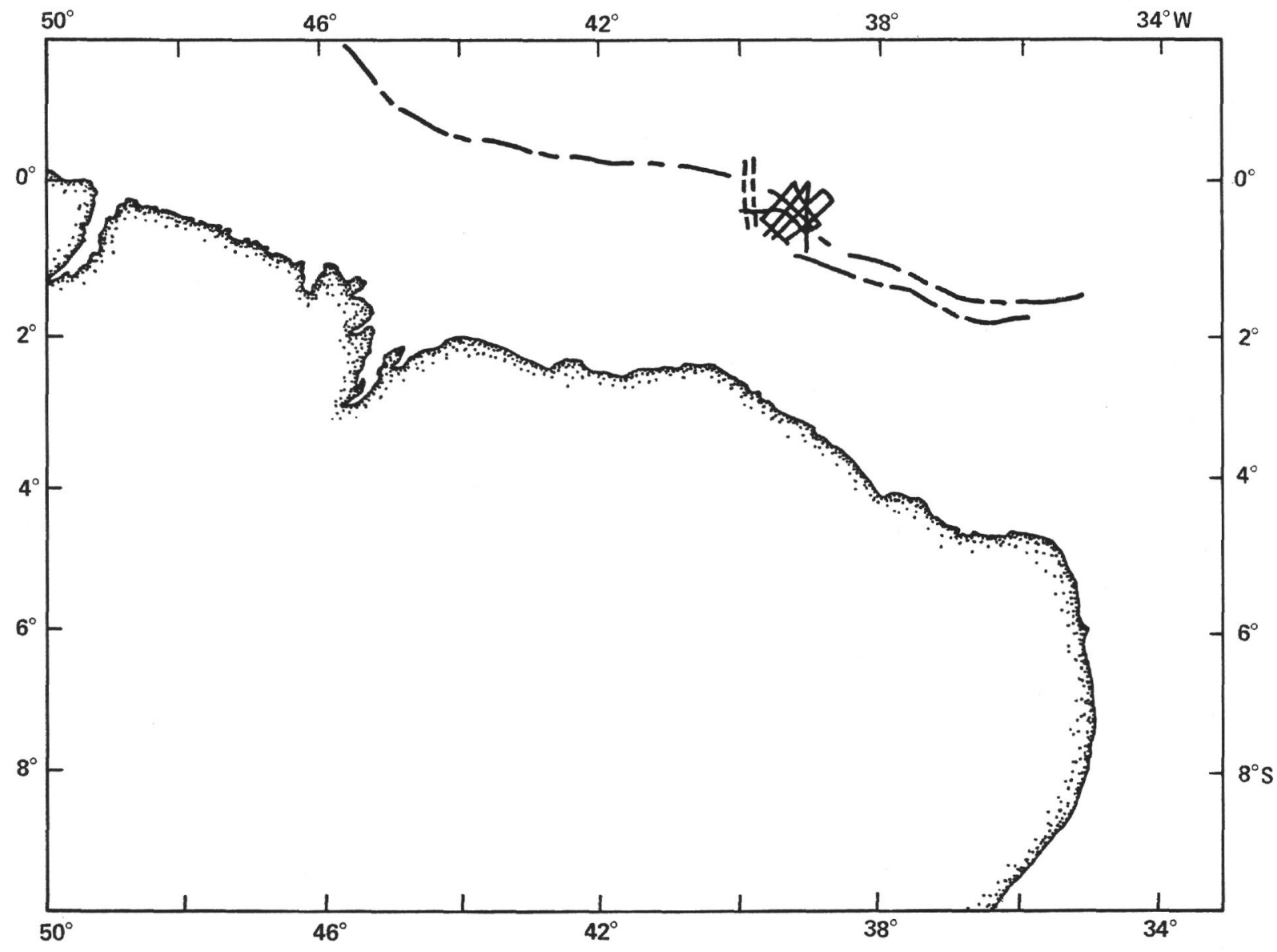

Figure 1. Chart showing the location of North Brazilian Ridge (after Hayes and Ewing, 1970). The track lines near $40^{\circ}$ W longitude show the area of the $\mathrm{R} / \mathrm{V}$ Vema site survey.

14. The known lateral extent of the Ridge coincides closely with that portion of northern South America that was juxtaposed with the east-west section of western Africa according to popular predrift reconstructions.

The above authors conclude that the Ridge appears to be a post-continental separation feature strongly influenced by the geometry of the newly created continental margin of northern Brazil. The present morphology is assumed to be primarily the result of volcanism which may have been active over several magnetic polarity epochs. A portion of the initial elevation of the Ridge presumably resulted from thermal expansion, and subsequent subsidence was due to cooling and isostatic readjustments.
The above data were not available to the JOIDES Atlantic Advisory Panel at the time when sites were recommended for Leg 4 of the Deep Sea Drilling Project. At the Leg 4 pre-cruise meeting in Miami, Florida, in January 1969, the Ridge site was proposed as an additional site to be investigated, if possible. Since the water depth and sediment thickness at this site were both minimal (2000 meters and less than 100 meters, respectively) and the location was not far from the track between initially planned sites, the shipboard party decided, upon completion of work at Site 24, to make a 24hour drilling effort on the North Brazilian Ridge.

The drilling objectives at this location were to sample and date the sediments atop the Ridge crest and to determine the nature, age and origin of the consolidated material beneath the thin mantle of sediment. 


\section{SITE SURVEY}

The $R / V$ Vema arrived in the area of Site 25 on February 11,1969 and proceeded to carry out topographic and geophysical surveys until February 13. Figure 2, constructed from the Vema echo-sounder measurements, illustrates the nature of the topography at Site 25 . The Ridge in this area is seen to be a relatively symmetrical, steep-sided feature with its long axis running NW-SE. The track along which seismic profiling was carried out is also shown in Figure 2. Line A-B represents a transect along which one seismic reflection profile was obtained perpendicular to the Ridge axis. This profile (V-26-1040, 1041, 1042) is reproduced in Figure 3 and shows the following typical Ridge features:

1. Symmetrical shape with side slopes of about 1:4.

2. Base 15 miles wide, crest 3.5 miles wide.

3. Crestal depth about 1000 fathoms, depth on continental side 2000 fathoms, oceanic side 2200 fathoms.

4. Intermediate reflecting horizon: continental side none, oceanic side approximately 3.5 seconds subbottom.

Refraction and reflection measurements reported by Hayes and Ewing (1970) (Figure 4) indicate that the Ridge crest is covered by a "transparent sediment layer approximately 250 to 300 meters thick, having an average sound velocity of $1.87 \mathrm{~km} / \mathrm{sec}$ overlying material of $3.8 \mathrm{~km} / \mathrm{sec}$." This transparent material is observed to have two intermediate reflectors, dividing the zone into three layers. It is probable that the uppermost of these reflectors corresponds to the contact between foraminiferal ooze and fragmented algal limestone, sampled in the drilling at Site 25 at 41 meters (134.5 feet) below bottom. A reflection profiler record taken aboard Glomar Challenger on an east-west crossing of Site 25 (Figure 5) shows an apparent 0.05 secondthick transparent layer, the base of which probably corresponds to this same contact, sampled at the bottom of Hole 25A and shown as the upper reflector in the Vema profile.

\section{DRILLING AND CORING OPERATIONS}

The Glomar Challenger reached the area of Site 25 on the morning of 10 February, 1969, guided by precise site location information, transmitted by D. Hayes, Chief Scientist aboard the $R / V$ Vema. The approach to the site was made on a westerly course, crossing the Ridge at 0830 . The reflection profiler record obtained on this crossing (Figure 5) revealed what appeared to be a sufficient depth of sediment to allow spudding-in on the western side of the summit. Upon completion of this traverse, the ship turned about, hauled in the towed equipment (air gun and magnetometer) and, guided by topography alone, returned to the desired position, which was later determined by a series of satellite navigation fixes at latitude $0^{\circ} 31^{\prime} \mathrm{S}$, longitude $39^{\circ} 14.40^{\prime} \mathrm{W}$. A position beacon was deployed at this location in 1916 meters (6287 feet; 1047 fathoms) depth, and the ship was operating in the automatic position-keeping mode by 1050 hours. The drill string was spudded in at 1945 hours on February 10, using a tungsten-carbide bit; coring commenced immediately. The first core, containing tan Globigerina ooze, was brought up at 2100 hours.

Table 1 lists the intervals drilled and the cores recovered at Hole 25. In the first four cores of oozes recovery was good, excepting Core 3 , which recovered only 7.5 per cent. Below the depth of 37 meters (120 feet) in the sediment, five coring attempts using a variety of drilling techniques produced no core recovery except for a single cobble-sized specimen of cemented carbonate rock from Core 7 ( 55 to 59 meters, 180 to 195 feet). The only other evidence of a formation change was a drilling break at approximately 46 meters (150 feet). At this level, corresponding to the estimated subbottom reflector depth, a distinctly harder formation was encountered. From the driller's estimates and the near total lack of recovery, it was thought that the drill bit was encountering a rock rubble of some hard material and that presumably some of this material had entered into the outer core barrel, preventing the inner barrel from seating. Therefore, after attempting Core 9, the drill string was tripped back to the sediment surface and spudded in again for Hole 25A at 0400 hours on February 11.

Hole $25 \mathrm{~A}$ was drilled to 39 meters (129 feet), where upon coring began. The first core contained 1.8 meters (6 feet) of foraminiferal ooze above a 0.6-meter (2foot) section of limestone cobbles containing shallowwater fossils. The boundary between the two materials in the core was marked by a cobble-sized manganese nodule. Two more cores were attempted immediately below with no recovery.

At 0900 hours on February 11, while attempting a fourth core in the interval below 59 meters (194 feet), the drill stem twisted off, the failure taking place at the upper bumper sub. This type of failure is, unfortunately, common when the drill bit encounters relatively hard material before the entire bottom hole assembly-142 meters (387 feet) in length-has penetrated below the mud line and has support from the walls of the hole. The drill string was recovered and the tools laid down by 1430 February 11, completing the work at this site.

\section{LITHOLOGIC SUMMARY}

For detailed lithology and paleontology see Hole Summaries. (See pages 69-76). 


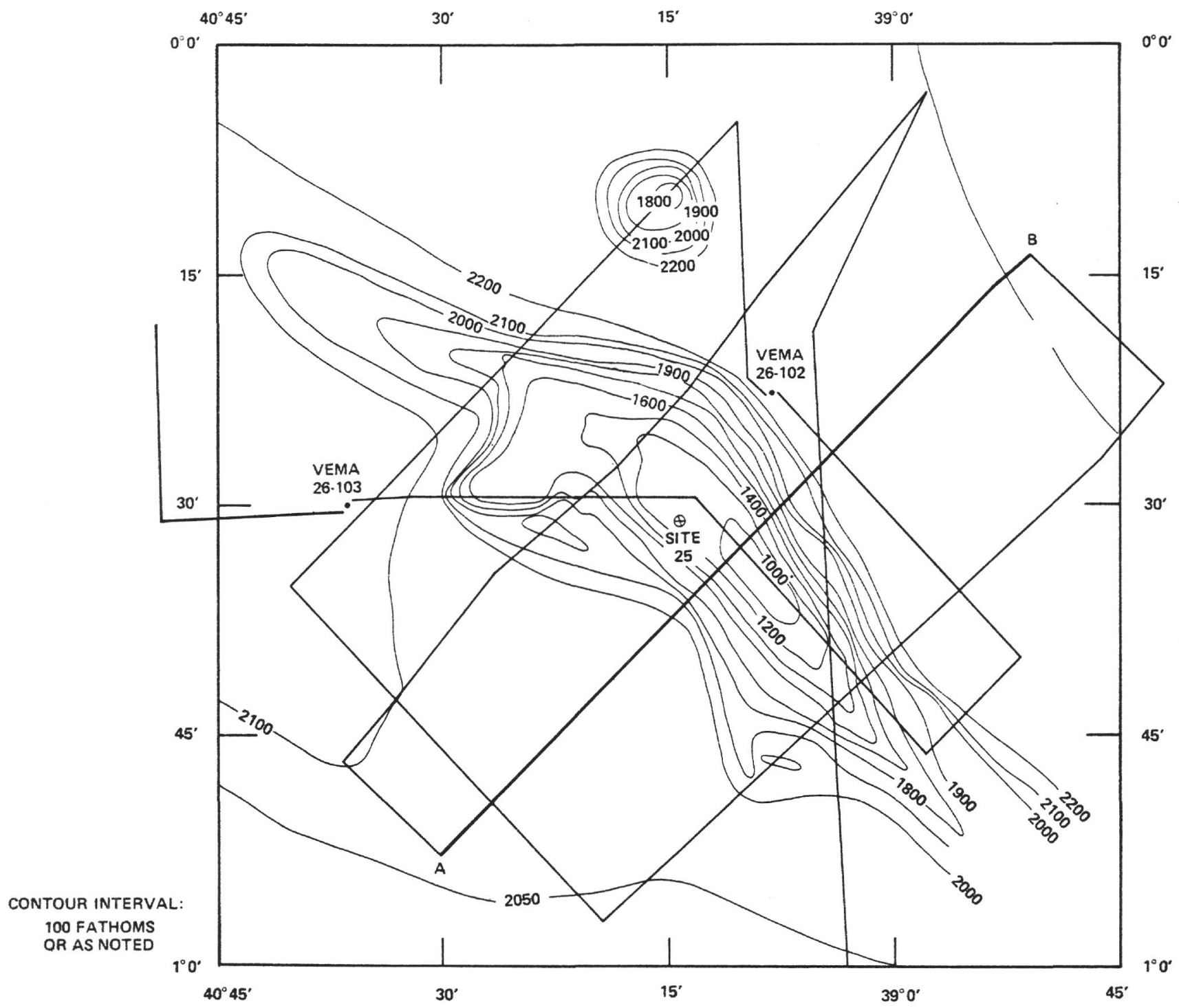

Figure 2. Topographic chart of North Brazilian Ridge in the vicinity of Site 25 based on R/V Vema survey. Contour interval is 100 fathoms except where noted. Light lines represent $\mathrm{R} / \mathrm{V}$ Vema track, Line A-B represents reflection profiler transect shown in Figure 3. The location of Vema piston core stations is also shown. 


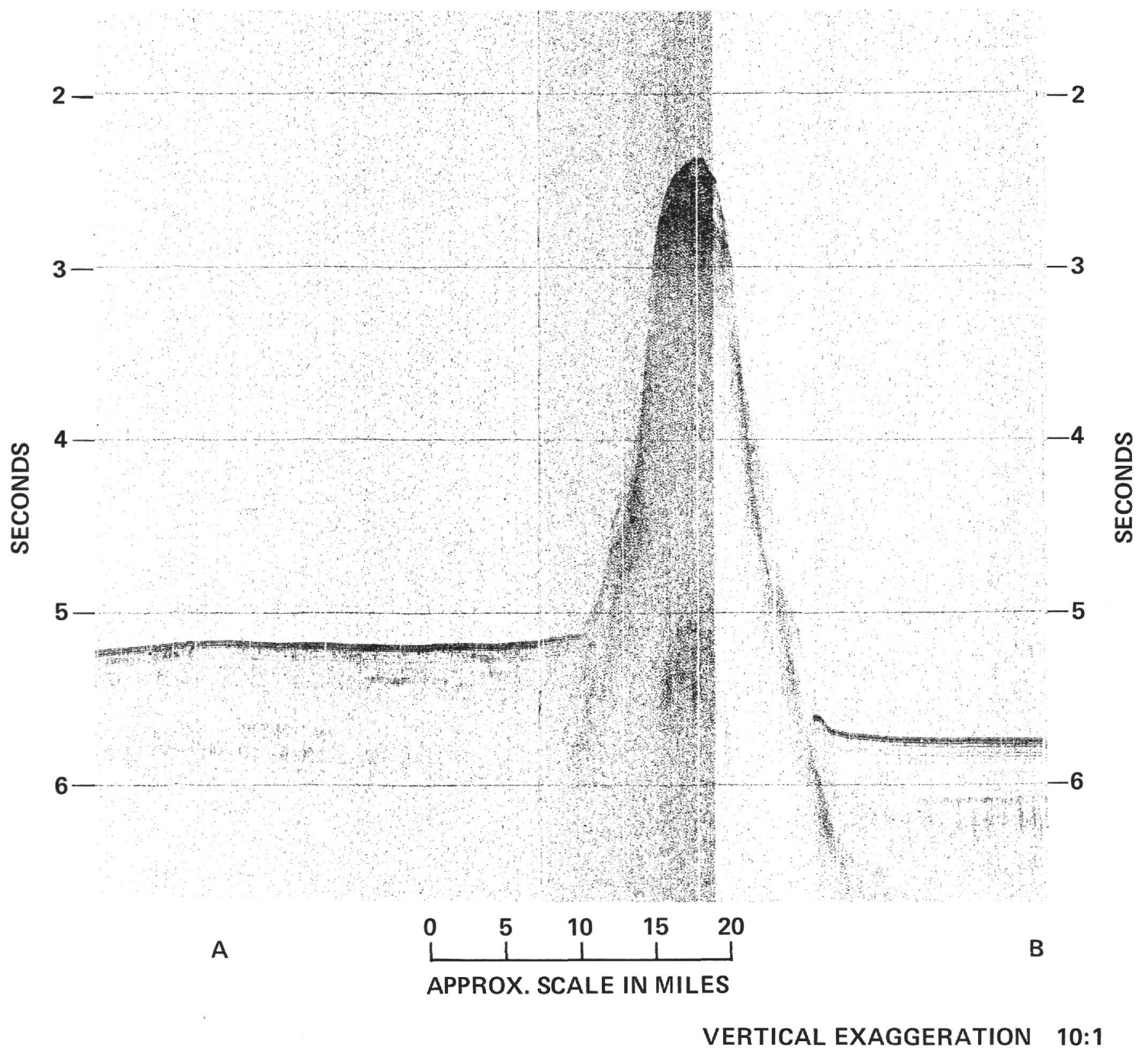

Figure 3. Vema reflection profiler record along transect A-B (Figure 1). Note the difference in bottom depth on opposite sides due to sediment ponding on the continental (left) side. The intermediate reflector on the oceanic (right) side is seen at approximately 3.5 seconds subbottom. 



Figure 4. Schematic sonic velocity section along North Brazilian Ridge axis near Site 25 based on reflection and refraction measurements. 


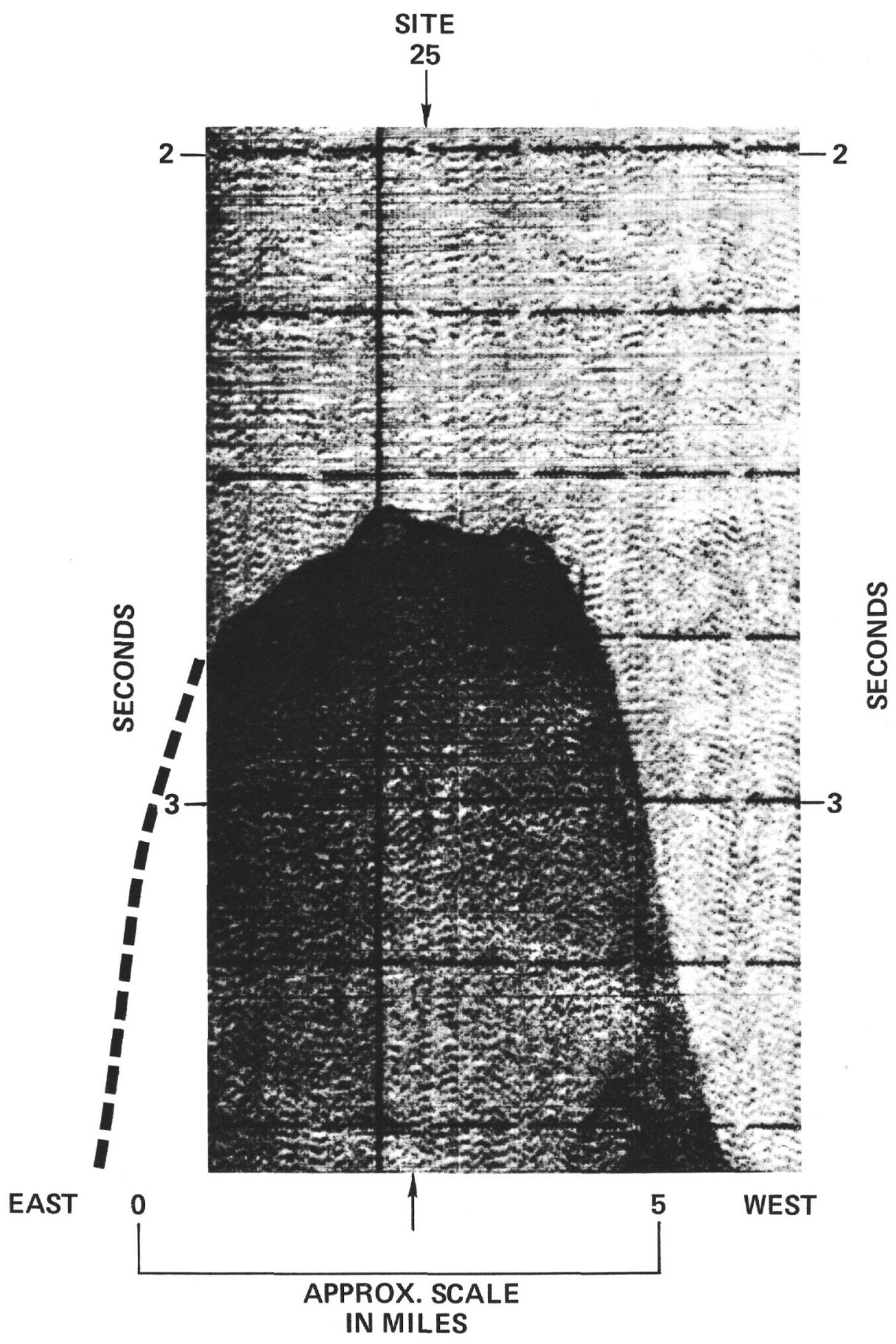

Figure 5. Glomar Challenger reflection profiler record across the crest of the North Brazilian Ridge near Site 25 showing an apparent .05 second thick "transparent" sediment layer. 
TABLE 1

Cores Recovered from Hole 25

(Using a Tungsten Carbide Bit)

\begin{tabular}{cccc}
\hline Core & $\begin{array}{c}\text { Drill String } \\
(\mathrm{m})\end{array}$ & $\begin{array}{c}\text { Penetration } \\
(\mathrm{m})\end{array}$ & $\begin{array}{c}\text { Core } \\
\text { Recovered } \\
(\mathrm{m})\end{array}$ \\
\hline 1 & $1937-1946$ & $0-9$ & 9.10 \\
2 & $1946-1955$ & $9-18$ & 3.00 \\
3 & $1955-1964$ & $18-27$ & 8.20 \\
4 & $1964-1974$ & $27-37$ & 5.00 \\
5 & $1977-1983$ & $37-46$ & 0.00 \\
6 & $1983-1992$ & $46-55$ & 0.00 \\
7 & $1992-1996$ & $55-59$ & 0.08 \\
8 & $1996-2001$ & $59-64$ & 0.00 \\
9 & $2001-2004$ & $64-67$ & 0.00 \\
\hline \multicolumn{3}{c}{ Total } \\
\hline
\end{tabular}

Cores Recovered from Hole 25A (Using a Tungsten Carbide Bit)

\begin{tabular}{cccc}
\hline Core & $\begin{array}{c}\text { Drill String } \\
(\mathrm{m})\end{array}$ & $\begin{array}{c}\text { Penetration } \\
(\mathrm{m})\end{array}$ & $\begin{array}{c}\text { Core } \\
\text { Recovered } \\
(\mathrm{m})\end{array}$ \\
\hline 1 & $1976-1985$ & $39-48$ & 2.7 \\
2 & $1985-1995$ & $48-58$ & 0.0 \\
3 & $1995-1996$ & $58-59$ & 0.0 \\
\hline & & Total & 2.7 \\
\hline
\end{tabular}

The sediments cored in Holes 25 and $25 \mathrm{~A}$ were of three different types: foraminiferal ooze, pebbly gravel and shallow water limestone.

In Hole 25 a reasonably complete section was recovered from the sea floor to about 110 feet ( 33.5 meters). The deposits consist entirely of light-colored oozes, comprised of large- and medium-sized foraminifera with varying amounts of nannoplankton, and ranging in age from late Pleistocene at the top to Late Middle Miocene at the bottom. Discoasters are especially abundant in the Miocene oozes. The lower Pleistocene and upper Pliocene oozes contain up to 10 per cent clay minerals and silt-size detritals; in all other parts of the section, detritals make up only one or two per cent of the deposits.

At 150 feet (45.7 meters) in Hole 25, the drill penetrated a harder bed. No core was recovered, but the core catcher had clayey ooze in which were mixed (from drilling) fragments of limestone gravel. The limestone fragments are of several colors and are sub-angular to sub-round. At least one of the small pebbles is a "conglomerate", consisting of sandstone-size fragments of limestone cemented by white calcium carbonate. Limonite occurs as flat fragments of "ironstone" and as staining on some of the pebbles. A few small pieces of hematite adhere to several of the pebbles, and one fragment of pyrite was noted. The small sample of gravel is obviously the result of erosion and redeposition of the underlying limestone under shallow water conditions.

From 150 to 180 feet ( 45.7 to 54.9 meters) no core was recovered; but the drill, after penetrating one hard layer from 150 to 155 feet ( 45.7 to 47.2 meters) went through alternating harder and softer beds that may well have been sand and gravel. No core was recovered from 180 to 195 feet ( 54.9 to 59.4 meters), but the core catcher had one large piece of fragmental limestone. The piece consists of algae, fragments of shells and byrozoa, plus pieces of white limestone, pyrite specular hematite and limonite. It is similar in appearance to certain types of modern reef limestone. Some of the matrix is recrystallized. This, plus the limonite, suggests that the sample has been weathered subaerially. From 195 to 225 feet (59.4 to 68.6 meters), there was no recovery, and Hole 25 was abandoned.

Hole $25 \mathrm{~A}$ was drilled in an attempt to recover more of the sedimentary rocks below the ooze. The first core run was from 162 to 192 feet (49.4 to 58.5 meters), and recovered about 8 feet ( 2.4 meters) of Miocene ooze plus a number of fragments of gray algal limestone coated with manganese oxide and two manganese nodules. The limestone, although similar to that from Hole 25 , is not fragmental and is certainly of shallow water origin-probably an inner reef facies. The stratigraphic position of the limestones in Holes 25 and 25A cannot be determined accurately with respect to each other, but they are probably both from very near the same horizon.

One of the manganese nodules from Hole 25A had a core of weathered limestone with veinlets of botryoidal limonite. This core is like some of the pieces of the limestone gravel noted in Hole 25.

There was no recovery from 192 to 252 feet (58.5 to 76.8 meters), where the lower 60 feet (18.3 meters) of the bottom assembly twisted off necessitating the abandonment of the hole.

\section{PHYSICAL PROPERTIES}

The cores from Site 25 were highly disturbed and the sediment thoroughly mixed with the drilling fluid. The 
cores were thought to bear no physical resemblance to the in situ sediment; no porosity, water content or small sample density measurements were made. Bulk density measurements yielded values close to $1.50 \mathrm{gm} / \mathrm{cc}$. Sonic velocities were generally in the range 1540 to 1545 $\mathrm{m} / \mathrm{sec}$. No chemical analyses were undertaken.

The natural gamma measurements are valid. While admixture of water may lower values a small amount, the radiation measurements still give the characteristic level for the type of sediment cored. All but three of the sections measured fall in the range $170-300$ counts/1.25 min. This is only 10 to 20 per cent higher than sea water background. A large proportion of water would be required to change the gamma radiation significantly.

The sediment cored at Site 25 is relatively pure foraminiferal ooze and has an expectably high carbonate content (63 to 82 per cent). The organic carbon content is low (nil to 0.2 per cent) with one exception ( 0.8 per cent).

\section{REFERENCES}

Hayes, D. E. and Ewing, M., 1968. Structure of the North Brazilian continental margin (Abstract). Bull. Geol. Soc. Am., Mexico City.

1970. The North Brazilian continental margin Am. Assoc. Petrol. Geol. (in press).

Heezen, B. C. and Tharp, M., 1961. Physiographic diagram of the South Atlantic. Bull. Geol. Soc. Am.

1968. Atlantic Ocean Floor. Nat. Geog. Soc. Carte Generale Bathymetrique des Oceans, 4eme edition, 1961. Feuille A'l. Monaco, Bur. Hydrographique Intern'1.

Chart of the World, No. 15, 254, Sheet 7. 1961. Washington, D. C. (U. S. Navy Hdyrographic Office). 


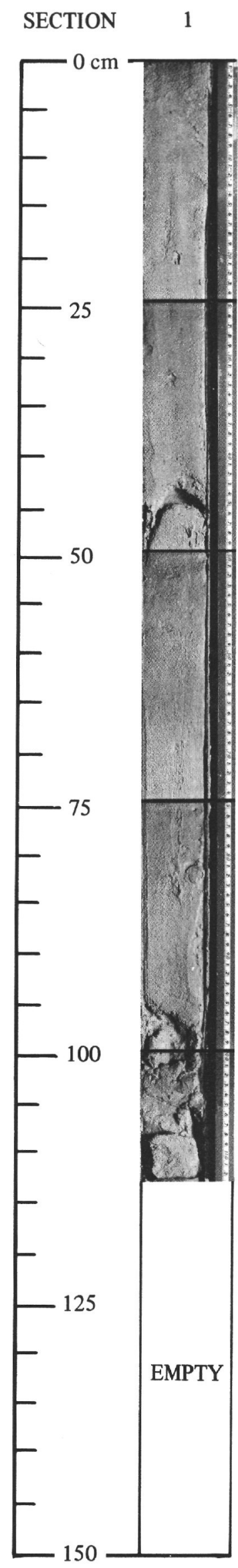

Plate 1. Core 1, Hole 25A. 


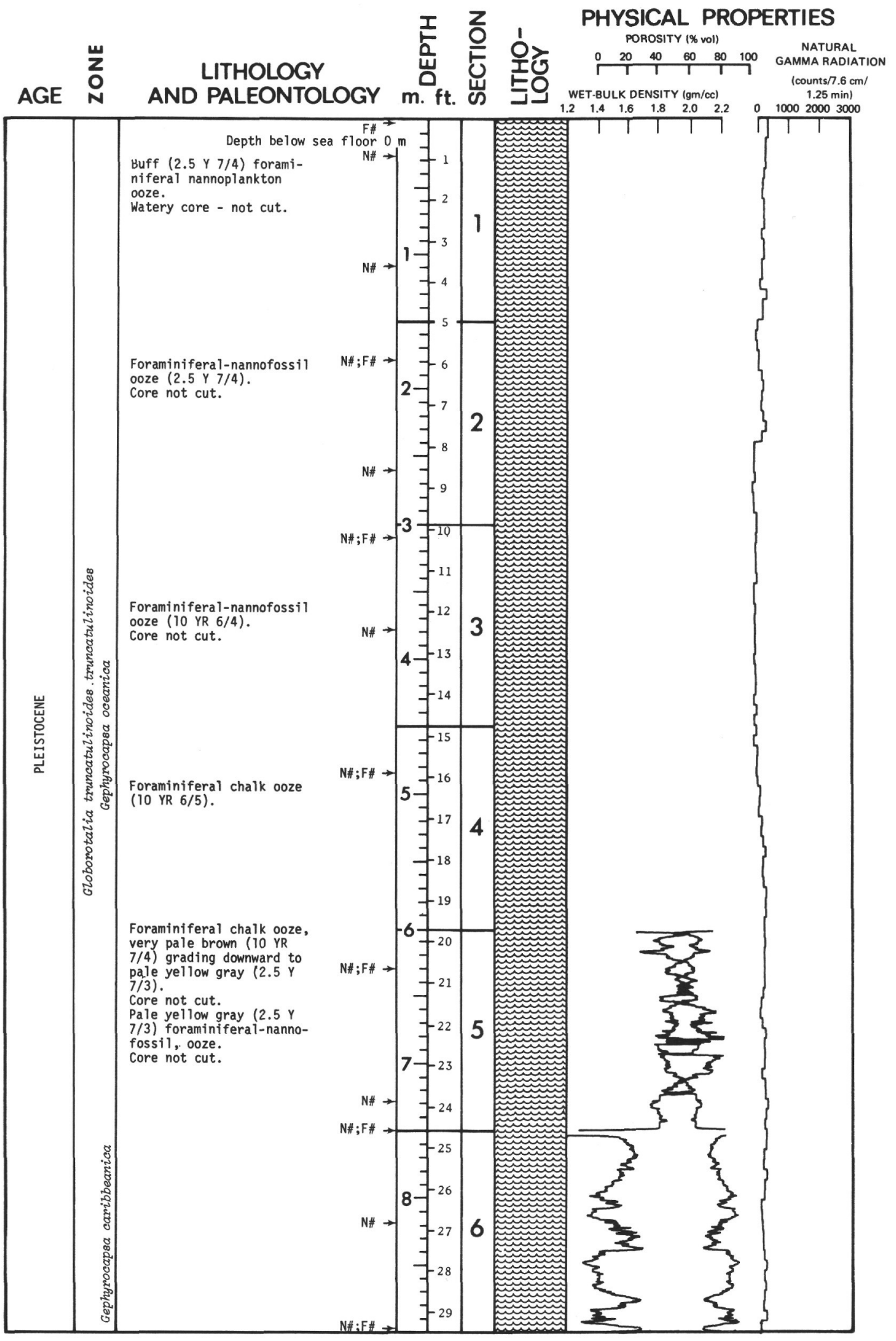

Figure 6. Core 1, Hole 25. 




Figure 7. Core 2, Hole 25. 


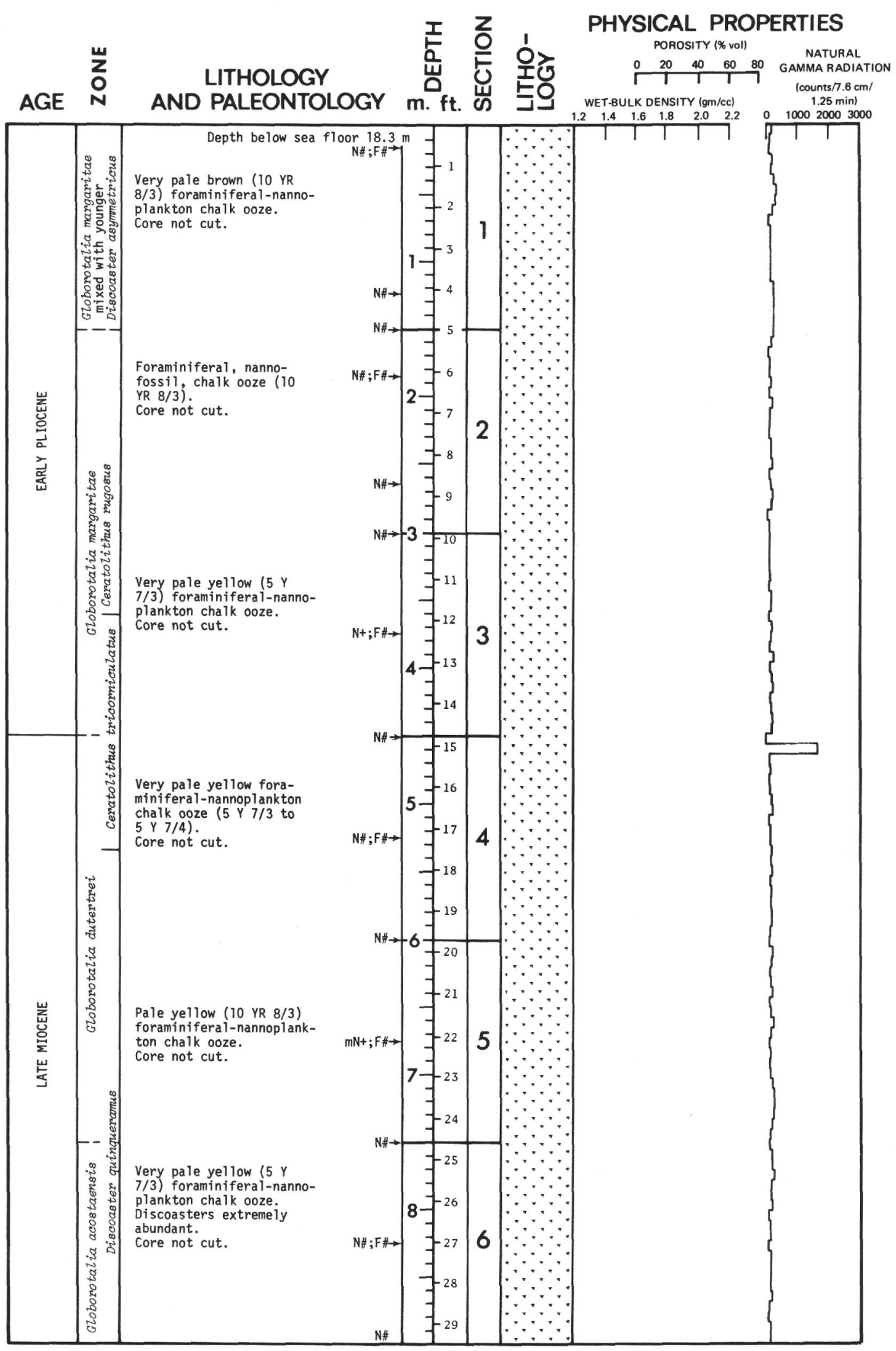

Figure 8. Core 3, Hole 25. 




Figure 9. Core 4, Hole 25. 


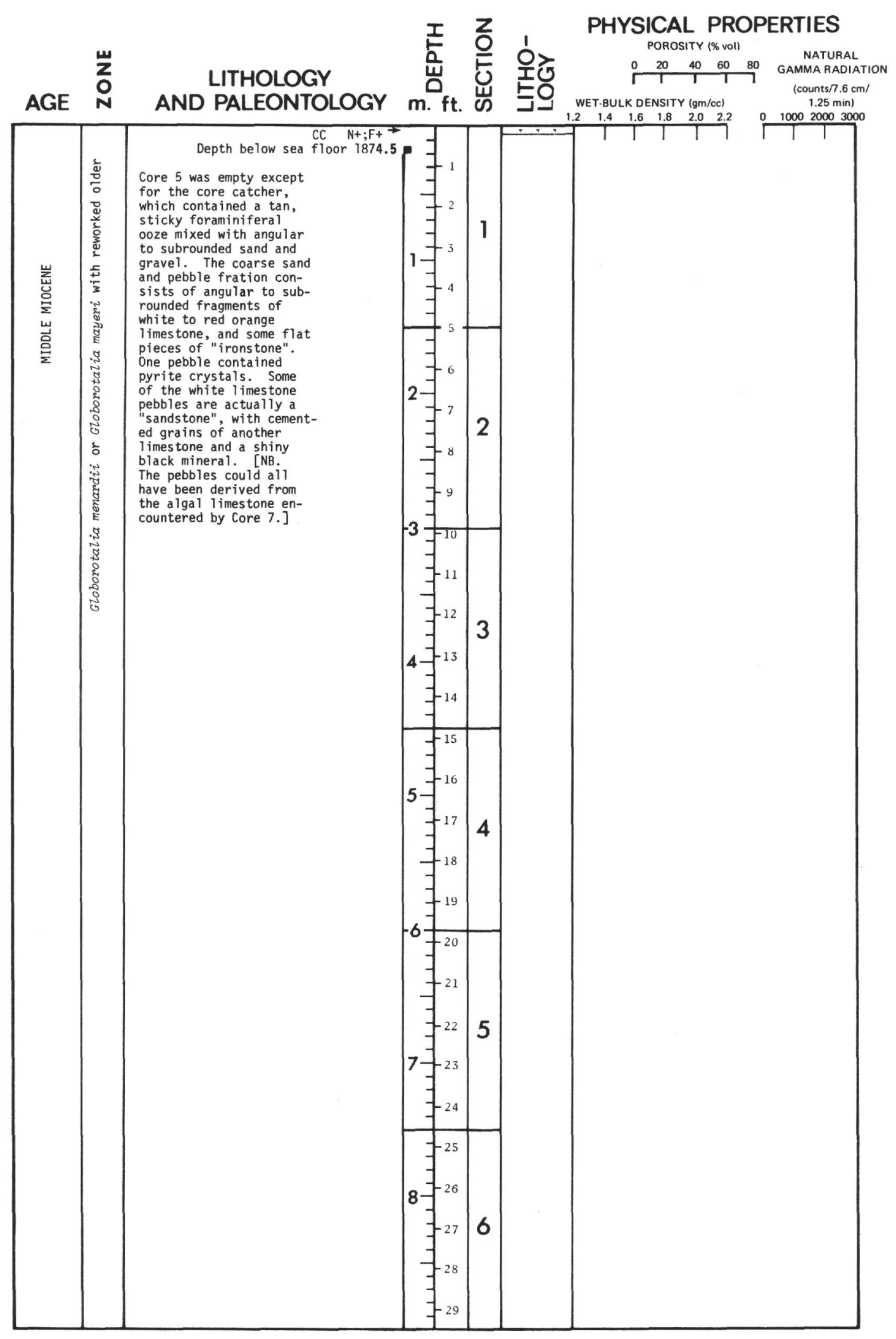

Figure 10. Core 5, Hole 25. 
NO CORE RECOVERED

Figure 11. Core 6, Hole 25. 




Figure 12. Core 7, Hole 25. 


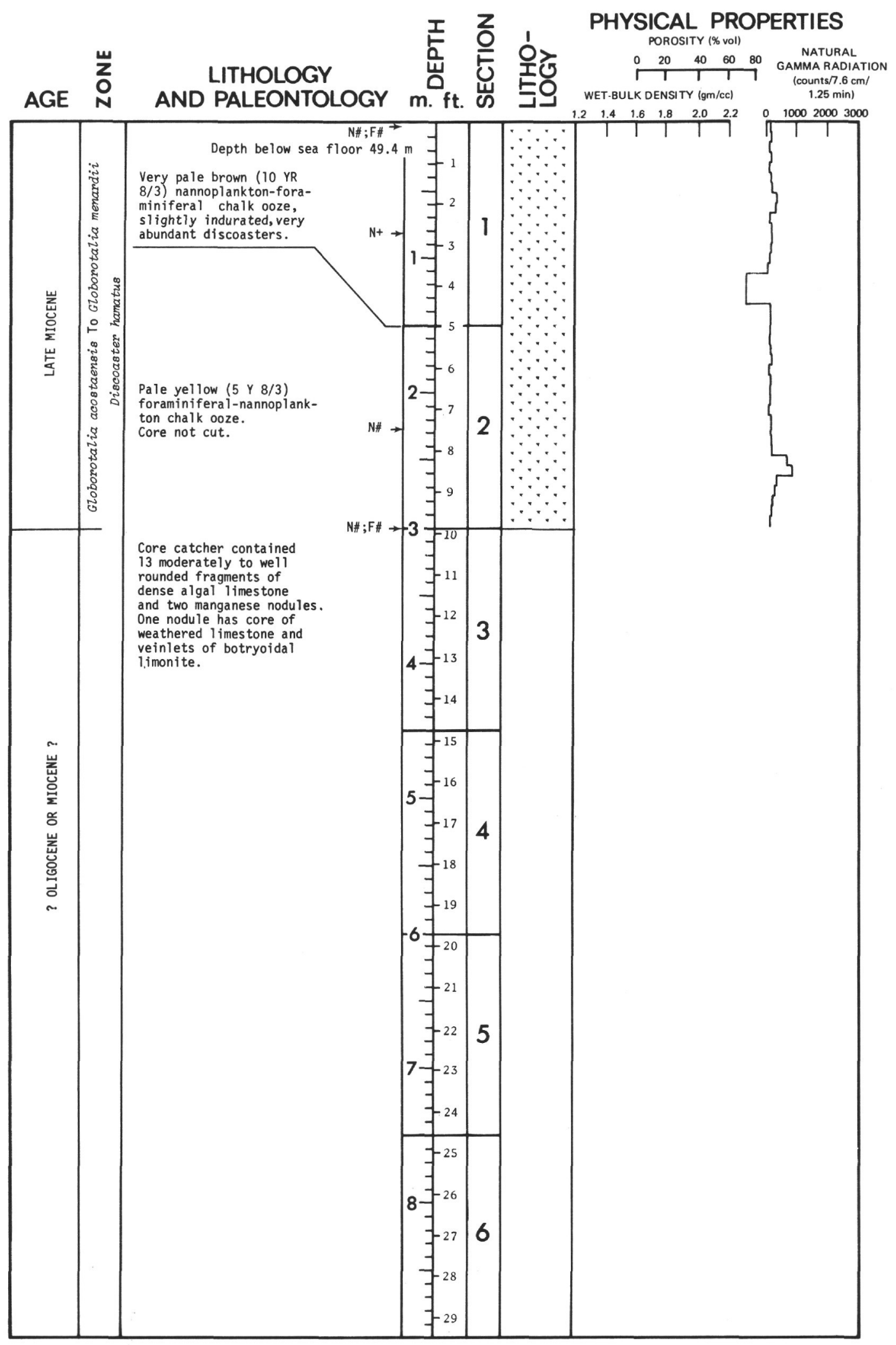

Figure 13. Core 1, Hole 25A. 